\title{
UTILIZATION OF DIFFERENT METHODS FOR EARLINESS MEASUREMENTS ON SOME EGYPTIAN COTTON GENOTYPES
}

\author{
(Received: 9.10.2014) \\ By \\ A. H. A. Mahdi, H. S. Khalifa ${ }^{*}$ and S. R. N. Said ${ }^{*}$ \\ Agronomy Department, Faculty of Agriculture, Fayoum University, Egypt \\ "Cotton Research Institute' Agriculture Research Center, Giza, Egypt
}

\begin{abstract}
The performances of three Egyptian cotton genotypes (Giza 90, Giza 90 x Aust. and [G.83 x (G.75 x5844)] x G.80) were evaluated for earliness using seven methods of measurements during 2013 and 2014 seasons. Date of flowering was estimated daily, and the average number of flowers for 10 plants per week was calculated to construct curves for weekly flowering. Moreover, this study included six measurements of earliness, i.e., position of first sympodial node (PFN), days to first flower (DFF), days to first open boll (DFB), earliness percentage ( $\mathrm{Er} \%)$, mean maturity date (MMD) and production rate index (PRI).

Rate of weekly flowering followed a normal distribution curve. The genotype (Giza $90 \mathrm{x}$ Aust.) produced the highest total number of flowers compared to other tested genotypes. The maximum average rate of flowering was found at fifteen week after planting (13/7-19/7). The total number of flowers was significantly different between genotypes. Also, the data showed significant differences in most flowering weeks.

Measurements of earliness (PFN, DFF, DFB, Er \%, MMD and PRI) indicated that (Giza $90 \mathrm{x}$ Aust.) was the earliest compared to other genotypes. Significant differences existed between the genotypes in (DFF, DFB, Er \% and MMD). While, the differences between genotypes were not significant for (PFN and PRI). The results obtained clarify that (Giza $90 \mathrm{x}$ Aust.) was the earliest compared to other genotypes.
\end{abstract}

Key words: cotton, earliness measurements, genotypes.

\section{INTRODUCTION}

Cotton (Gossypium barbadanse L.) is considered the main fiber crop through industry in Egypt and in the world. In Egypt, it was always and still the main cash crop for most growers. It is the main raw material used in textile industry, which is one of the most successful industries in Egypt.

Earliness in cotton has many advantages. It helps to fit the crop into a multi-cropping system. The losses of yield, its components and fiber properties quality from disease and insect injury, may be reduced by the use of early maturing varieties. Earliness in cotton is not a character that can be easily measured since the cotton plant flowers and sets bolls over a long period of time. Earliness is influenced by the time of flowering, rapid development of flowers and the length of time required for the bolls to mature.
The progress of any breeding program depends on the available genetic variation to produce new superior genotypes that can replace the existing ones. Cotton breeders have special interest in developing new promising genotypes.

Thus, the study of the methods of measuring earliness in cotton is very important in cotton breeding programs in order to evaluate and select early mature varieties. Abd El-Rahman and Abo-Tour (1994), Awaad (1994), Badr et al. (2001), Haneef et al. (2001), Badr (2003), ElAdly (2003), Sawan (2009), Sawan et al. (2005 and 2010), Dhamayanthi and Rathinavel (2013) and Sawan (2014), studied the flowering behavior in cotton genotypes using flowering curves. However, Richmond and Radwan (1962), Al-Enani and Eid (1980), Shafshak et al. (1993), El- Agamy et al. (1994), Nassar et al. (1998), Badr et al. (2001), Badr (2003), El-Adly (2003), Shah et al. (2010), Ismail et al. (2012), 
Shakeel et al. (2012), and Habib et al. (2013), studied earliness by measuring position of the first fruiting node, day to first flower and earliness percentage. Awaad (1994), Nassar et al. (1998) Abo El-Zahab et al. (2003) and Ismail et al. (2012), estimated the mean maturity date and production rate index as an indication to crop maturity.

Our objective in this study was to evaluate three Egyptian cotton genotypes for maturity by using seven earliness measurements.

\section{MATERIALS AND METHODS}

Two field experiments were carried out at Sids Agricultural Research Station, Bani-Swef Governorate, Middle Egypt during 2013 and 2014 seasons. The main aim was to study some earliness measurements on the three Egyptian cotton genotypes (Giza 90, Giza 90 x Aust. and [G.83 x (G.75 x5844)] x G.80). Randomized Complete Block Design with three replications was used. The plots were of five rows; 4.0 meters long and $60 \mathrm{~cm}$ wide. Seeds were planted in hills $20 \mathrm{~cm}$ apart and thinned to two healthy plants on the last week of March in both seasons. All cultural practices were applied as recommended in cotton fields.

Data of flowering were estimated daily on ten guarded plants, which were taken from the outer rows of each plot. Flowering date was recorded on labels which were hanged to the flowers. The number of flowers of ten plants on each plot at the three replicates were counted at weekly intervals during the eleven weeks of the flowering period. The other plants were used to measure the following characters:

1-Flowering behaviour: The curves of flowering were constructed using the number of flowers counted weekly during the eleven weeks.

2-Position of the first sympodial node (PFN) Position of the main stem node at which the first fruiting branch emerges was expressed as number of nods.

3-Days to first flower (DFF): The number of days from planting to the opening of the first flower.

4-Days to first open boll (DFB): Number of days from sowing to the opening of the first boll.
5-Earliness percentage ( $\mathrm{Er} \%$ ): Was calculated according to the following equation:

$$
\begin{gathered}
\text { yield of the first pick } \\
\text { Earliness index }=\text {--aight of the two picks } \\
\text { Weick }
\end{gathered}
$$

Pickings were carried out by hand on weekly basis on the three middle rows of each plot. Seven pickings were made in each of the two seasons at the dates specified in Table (1). The following characters were determined for each genotype.

Table (1): Dates of weekly picking in 2013 and 2014 seasons.

\begin{tabular}{|c|c|c|c|c|c|c|}
\hline \multicolumn{7}{|c|}{ Picking dates } \\
\hline P1 & P2 & P3 & P4 & P5 & P6 & P7 \\
\hline $11 / 8$ & $18 / 8$ & 25 / 8 & 1/9 & 8/9 & 15/9 & $22 / 9$ \\
\hline
\end{tabular}

6-Mean maturity date (MMD): Weight mean of harvest date of several periodic harvests calculated according to Christidis and Harrison (1955) by the following formula:

$\mathrm{MMD}=\left(\mathrm{W}_{1} \mathrm{H}_{1}+\mathrm{W}_{2} \mathrm{H}_{2}+\ldots \ldots \ldots .+\mathrm{W}_{\mathrm{n}} \mathrm{H}_{\mathrm{n}}\right)$

Where:

$\mathrm{W}=$ weight of seed cotton in grams.

$\mathrm{H}=$ number of days from planting to harvest.

$1,2, \ldots \ldots$ and $\mathrm{n}=$ consecutive period harvest number (7 harvests).

7- Production rate index (PRI): Calculated by dividing the total seed cotton yield by MMD value which results in relative production rate (amount per unit time) according to Bilbro and Quisenberry (1973).

The general formula for this value would be:

Where:

$$
\begin{gathered}
\mathrm{PRI}=\left(\mathrm{W}_{1}+\mathrm{W}_{2}+\ldots \mathrm{W}_{\mathrm{n}}\right)^{2} / \\
\left(\mathrm{W}_{1} \mathrm{H}_{1}+\mathrm{W}_{2} \mathrm{H}_{2}++\mathrm{W}_{\mathrm{n}} \mathrm{H}_{\mathrm{n}}\right)
\end{gathered}
$$

$\mathrm{W}=$ weight of seed cotton in grams.

$\mathrm{H}=$ number of days from planting to harvest.

$1,2, \ldots$ and $\mathrm{n}=$ consecutive period harvest number (7 harvests).

The data obtained were subjected to statistical analysis according to the procedures outlined by Snedecor and Cochran (1967). Means values of the studied characters were compared by L.S.D. test at $5 \%$ level of significance. 


\section{RESULTS AND DISCUSSION}

The results reported in this study include the evaluation of the three Egyptian cotton genotypes (Giza 90, Giza 90 x Aust. and [G.83 x (G.75 x5844)] x G.80) using seven methods for measuring earliness. These results are summarized as follows:

\subsection{Flowering behaviour}

The data of weekly flowering intervals are contained in Table (2). The flowering season extended for eleven weeks at the two growing seasons 2013 and 2014, respectively. The genotype (Giza 90 x Aust.) produced total number of flowers per plant more than any other genotypes. With respect to weekly flowering, it followed a normal curve which was nearly similar in all genotypes in both growing seasons, Figs. (1 and 2). The average rate of flowering results are in general agreement with those previously reported by Abd El-Rahman and Abo-Tour (1994), Awaad (1994), Badr et al. (2001), Haneef et al. (2001), Badr (2003), ElAdly (2003), Sawan (2009), Sawan et al. (2005 and 2010), Dhamayanthi and Rathinavel (2013) and Sawan et al. (2014).

3.2. Position of the first sympodial node (PFN)

Data in Table (3) indicate insignificant differences between the genotypes under study in the two seasons for (PFN). The genotype (Giza 90 x Aust.) had the lowest position of the first fruiting node (6.59), while (PFN) for Giza 90 and [G.83 x (G.75 x5844)] x G.80 were (7.00 and 6.83), respectively. These results are in agreement with those obtained by Awaad (1994) El-Agamy et al. (1994), El-Adly (2003) and Habib et al. (2013).

Table (2): Number of flowers/10 plants in the three Egyptian cotton genotypes at weekly intervals in 2013 and 2014 seasons.

\begin{tabular}{|c|c|c|c|c|c|}
\hline \multirow{3}{*}{$\begin{array}{c}\text { Weeks after } \\
\text { planting }\end{array}$} & \multirow{3}{*}{$\begin{array}{c}\text { Flowering } \\
\text { period }\end{array}$} & \multicolumn{3}{|c|}{ Cotton genotypes } & \multirow[b]{2}{*}{ L.S.D. $5 \%$} \\
\hline & & Giza 90 & $\begin{array}{c}\text { Giza } 90 \times x \\
\text { Aust. }\end{array}$ & $\begin{array}{c}G .83 \times(G .75 \times \\
5844)] \times \text { X.80 } \\
\end{array}$ & \\
\hline & & \multicolumn{4}{|c|}{2013 season } \\
\hline 11 & $15 / 6-21 / 6$ & 4.6 & 6.5 & 7.3 & N.S. \\
\hline 12 & $22 / 6-28 / 6$ & 13.8 & 16.4 & 16.8 & 1.3 \\
\hline 13 & $29 / 6-5 / 7$ & 26.4 & 31.8 & 26.6 & 3.5 \\
\hline 14 & $6 / 7-12 / 7$ & 31.9 & 42.2 & 30.1 & 9.3 \\
\hline 15 & $13 / 7-19 / 7$ & 45.0 & 57.0 & 53.0 & 11.6 \\
\hline 16 & $20 / 7-26 / 7$ & $\mathbf{3 3 . 5}$ & 38.3 & 38.5 & N.S. \\
\hline 17 & $27 / 7-2 / 8$ & 25.6 & 33.9 & 26.8 & N.S. \\
\hline 18 & 3/8-9/8 & 11.4 & 14.4 & 9.0 & 2.4 \\
\hline 19 & $10 / 8-16 / 8$ & 9.4 & 10.6 & 5.3 & 4.2 \\
\hline 20 & 17/8-23/8 & 3.2 & 6.8 & 2.5 & 1.5 \\
\hline 21 & $24 / 8-30 / 8$ & 1.4 & 3.7 & 1.0 & 1.3 \\
\hline \multicolumn{2}{|c|}{ Total } & 206.2 & 261.6 & 216.9 & 25.7 \\
\hline \multicolumn{6}{|c|}{2014 season } \\
\hline 11 & $15 / 6-21 / 6$ & 7.7 & 7.3 & 7.5 & N.S. \\
\hline 12 & $22 / 6-28 / 6$ & 17 & 25.8 & 11.4 & 2.7 \\
\hline 13 & $29 / 6-5 / 7$ & 24.9 & 31.9 & 21.3 & 7.3 \\
\hline 14 & $6 / 7-12 / 7$ & 30.1 & 40.8 & 29.7 & 9.5 \\
\hline 15 & $13 / 7-19 / 7$ & 43 & 53.7 & 49.0 & 8.6 \\
\hline 16 & $20 / 7-26 / 7$ & 35.7 & 33.5 & 34.3 & N.S. \\
\hline 17 & $27 / 7-2 / 8$ & 27 & 21.7 & 25.7 & N.S. \\
\hline 18 & 3/8-9/8 & 7.8 & 16.5 & 15.4 & 4.3 \\
\hline 19 & 10/8-16/8 & 5.1 & 7.6 & 9.5 & 1.5 \\
\hline 20 & 17/8-23/8 & 2.1 & 4.8 & 5.8 & 2.7 \\
\hline \multirow{2}{*}{\multicolumn{2}{|c|}{$24 / 8-30 / 8$}} & 1.2 & 2.0 & 3.1 & N.S. \\
\hline & & 2016 & 245.6 & 212.7 & 29.5 \\
\hline
\end{tabular}

started slow, then it increased gradually, reached the peak in the fifteen week after planting (13/719/7) and then decreased gradually till it reached its minimum at the fourth week of august. These

\subsection{Days to first flower (DFF)}

Results in Table (3) revealed significant differences between the genotypes for days to first flower. The genotype (Giza 90 x Aust.) was 


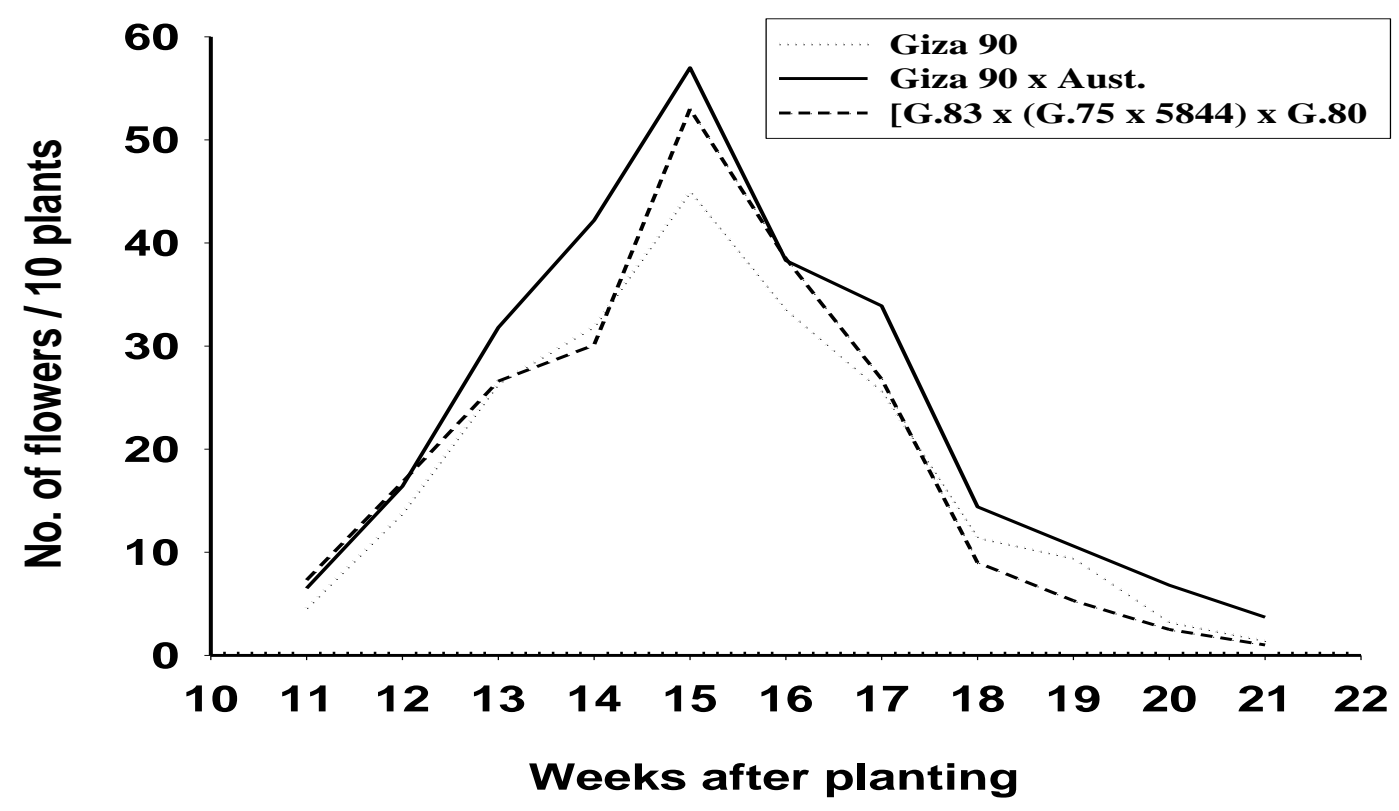

Fig. (1): The flowering curve of the studied genotypes (Giza 90, Giza 90 x Aust. and $G .83 \times(G .75 \times 5844)]$ x G.80 in 2013 season.

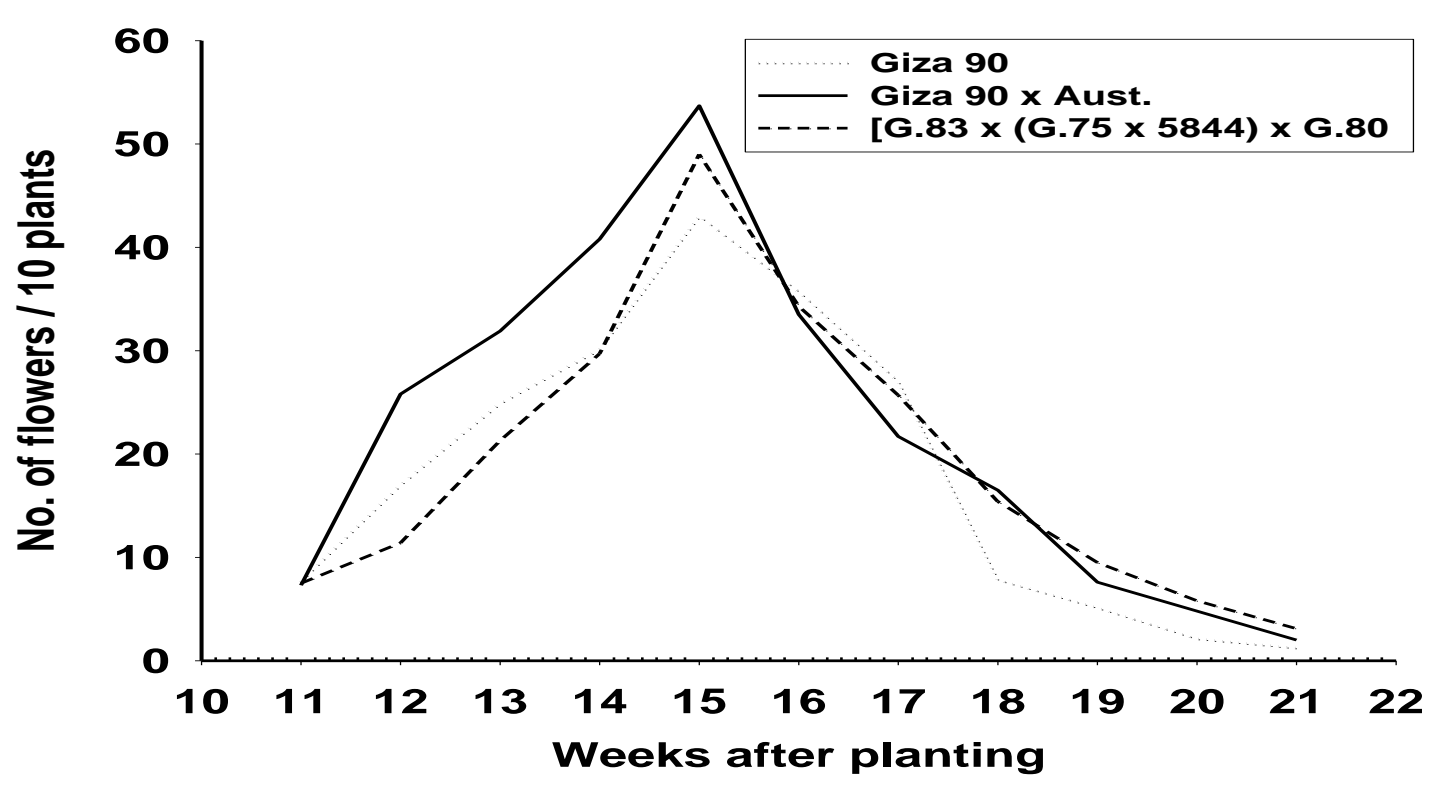

Fig. (2): The flowering curve of the studied genotypes (Giza 90, Giza 90 x Aust. and $\mathbf{G . 8 3} \times(\mathbf{G . 7 5} \times 5844)]$ x G.80 in 2014 season. 
the earliest genotype in this trait (82.55 and 80.32 days) in the two seasons, respectively. These results may be attributed to the differences among cotton genotypes in genetical constitution and their adaptability with environmental conditions which were reflected on flowering and fruiting. Similar results were obtained by Shafshak et al. (1993), Awaad (1994), Badr (2003), El-Adly (2003), Ismail et al. (2012) and Habib et al. (2013).

\subsection{Days to the first open boll (DFB)}

It could be seen from Table (3) that during 2013 and 2014 seasons, significant differences were found between the genotypes for days to first open boll. The genotype (Giza 90 x Aust.) had the lowest number of days from planting to the first open boll. The results indicated that there is potential for the development of early maturing genotypes by using available germplasm advancing early maturing. The results are in harmony with those obtained by Shafshak et al. (1993), Badr (2001) El-Adly (2003) and Ismail et al. (2012).

\subsection{Earliness percentage ( $\mathrm{Er} \%)$}

Data in Table (3) showed means of earliness percentage in both seasons. These genotypes revealed that earliness percentage in 2013 ranged from $60.23 \%$ to $68.54 \%$, also in 2014 ranged from $61.58 \%$ to $69.57 \%$. Significant differences existed between the genotypes in this character. The genotype (Giza 90 x Aust.) had the highest earliness percentage in the two seasons. In this respect, Awaad (1994), Badr (2001), Badr (2003) and Ismail et al. (2012), noted that the effect of genotypes was significant on earliness percentage.

\subsection{Mean maturity date (MMD)}

The results shown in Table (3) indicate that the differences varied significantly with respect to the mean maturity date at $5 \%$ value, although, the differences between the lowest and the highest period rate were only 7 days. The genotype (Giza 90 x Aust.) had the lowest MMD (142.11 and 141.12 days) during 2013 and 2014 seasons, respectively. Abo El-Zahab et al. (2003) and Ismail et al. (2012), pointed that MMD was considered to be the most discriminating and reliable method of estimating earliness regardless to yield.

\subsection{Production rate index (PRI)}

Regarding the production rate index presented in Table (3), it was obvious that the differences among the genotypes were insignificant in the two seasons. The genotype (Giza 90 x Aust.) was earlier than the other genotypes, followed by [G.83 x (G.75 x 5844)] x G.80 and Giza 90 respectively. El-Adly (2003) and Ismail et al. (2012) reported that PRI method of measuring earliness revealed the cultivars that have superior combinations of yield and earliness.

Table (3): Mean number of position of the first sympodial node (PFN), days to the first flower (DFF), days to the first open boll (DFB), earliness percentage ( $\mathrm{Er} \%)$, mean maturity date (MMD in days) and production rate index (PRI in gram) for three Egyptian cotton genotypes in 2013 and 2014 seasons.

\begin{tabular}{|c|c|c|c|c|}
\hline \multirow{3}{*}{ Characters } & \multicolumn{3}{|c|}{ Cotton genotypes } & \multirow[b]{2}{*}{ L.S.D. $5 \%$} \\
\hline & $\begin{array}{c}\text { Giza } \\
90\end{array}$ & $\begin{array}{l}\text { Giza 90 } \\
\text { x Aust. }\end{array}$ & $\begin{array}{c}\text { [G.83 x (G.75 x } \\
5844)] \text { x G.80 }\end{array}$ & \\
\hline & \multicolumn{3}{|c|}{2013 season } & \\
\hline Position of the first sympodial node (PFN) & 7.00 & 6.59 & 6.83 & N.S. \\
\hline Days to the first flower (DFF) & 87.24 & 82.55 & 85.03 & 2.31 \\
\hline Days to the first open boll (DFB) & 137.56 & 131.92 & 134.73 & 3.33 \\
\hline Earliness percentage ( $\mathrm{Er} \%)$ & 60.23 & 68.54 & 64.03 & 4.10 \\
\hline Mean maturity date (MMD in days) & 149.13 & 142.11 & 146.23 & 2.94 \\
\hline Production rate index (PRI in gram) & 0.75 & 0.81 & 0.79 & N.S. \\
\hline \multicolumn{5}{|c|}{2014 season } \\
\hline Position of the first sympodial node (PFN) & 6.87 & 6.43 & 6.75 & N.S. \\
\hline Days to the first flower (DFF) & $\mathbf{8 5 . 8 1}$ & 80.32 & 83.21 & 2.53 \\
\hline Days to the first open boll (DFB) & 137.85 & 131.25 & 134.21 & 3.12 \\
\hline Earliness percentage (Er \%) & 61.58 & 69.57 & 65.23 & 4.21 \\
\hline Mean maturity date (MMD in days) & 148.35 & 141.12 & 145.67 & 2.70 \\
\hline Production rate index (PRI in gram) & 0.65 & 0.73 & 0.63 & N.S. \\
\hline
\end{tabular}




\section{Conclusions}

From the above results of earliness measurements, it could be concluded that the genotype (Giza 90 x Aust.) was earlier than the other genotypes. Flowering behavior, position of the first sympodial node, days to the first flower, days to the first open boll, earliness percentage, mean maturity date and production rate index methods gave the same genotype ranking.

\section{REFERENCES}

Abd El-Rahman Laila M. A. and Abo-Tour H. B. (1994). Effect of seasonal variation on flowering and fruiting on cotton. Agric. Res. Tanta Univ., 20 (1): 37-47.

Abo El-Zahab A. A., Awad H. Y. and Baker K. M. A. (2003). Comparative performances of Pima and Egyptian cotton cultivars: I.Cotton yield and its components, Earliness in maturity and fiber properties. Egypt. J. Agric. Res., 81(1): 273-254.

Al-Enani F. A. A. and Eid E. (1980). Comparative study in some Egyptian cotton varieties. 1-A study of flowering behavior. Agric. Res. Rev., 58: 1-12.

Awaad M. M. (1994). Studies of earliness in some Egyptian cotton genotypes. Proc. $6^{\text {th }}$ conf. Agron, Al-Azhar Univ., Cairo, Egypt, 1: 41-58.

Badr S. S. M. (2003). Evaluation of some Egyptian cotton varieties by the yield and seven methods of earliness of crop maturity measurements. Egypt. J. Agric. Res., 81(2): 671-687.

Badr S. S. M., Hassan I. S. M. and Abd ElRahman, Laila M. A. (2001). Comparative study on flowering, yield components and lint properties of some new Egyptian cotton cultivars. J. Agric. Sci. Mansoura, 26 (6): 3473-3486.

Bliboro J. D. and Quisenberry J. E. (1973). A yield related measure of earliness for cotton. (G. hirsutum L.). Corp Sci., 13: 392-393.

Christidis B. G. and Harrison G. J. (1955). Cotton growing problems. McGraw-Hill Book Co., Inc., New York, PP. 633.

Dhamayanthi K. P. M. and Rathinavel K. (2013). Studies on flowering behaviour and fruiting pattern of early maturing germplasm lines of Egyptian cotton. Cotton Res. J. 5 (2): 150-157.
El-Adly H. H. (2003). Earliness study on new Egyptian cotton genotypes. Egypt. J. Agric. Res., 81(4): 1783-1796.

El-Agamy A. I., Okaz A. M., Awad H. Y. and Mohamed S. A. S. (1994). Evaluation of six methods used to measure earliness in some interspeecific crosses of cotton. Proc. $6^{\text {th }}$ conf. Agron., Al-Azhar Univ. Cario, Egypt.

Habib S., Azhar F. M., Manzoor T. Aulak M. A. and Farooq Sh. (2013). Study of biochemical and agronmmic traits relating to earliness in cotton. J. Agric. Res., 51 (2): 109-119.

Haneef M., Arshad M., Haidar S., Afzal M., Rashid M. and Oamar Z. (2001). The flowering and fruiting behaviour of some commercial varieties of cotton ( $G$. hirsutum L.). Pak. J. Bio. Sci., 4 (8): 940944.

Ismail F. M., Dewdar M. D. H. and Mahdi A. H. A. (2012). Multiple regression and correlation analysis of earliness and potential traits of five cotton varieties ( $G$. barbadense L.) grown under different environments. Bull. Fac. Agric., Cairo Univ., 63: 386-395.

Nassar M. A. A., Hossam El-Dein A. E., Awaad M. M. and El-Adly H. H. (1998). Genetical studies of earliness measurements in two inter specific crosses of cotton. Adv. Agric. Res, Alex. Univ., 3 (3): 395-411.

Richmond T. R. and Radwan S. A. H. (1962). A comparative study of seven methods of measuring earliness of crop maturity in cotton. Crop. Sci., 2: 379-400.

Sawan Z. M. (2009). Response of flower and boll development to climatic factors in Egyptian cotton. Climate Change, 97, 553-591.

Sawan Z. M. (2014). Statistical study: Nature relationship between climatic variables prevailing prior to flowering or subsequent to boll setting and cotton production. Nat. Sci., 6: 583-596.

Sawan Z. M., Li H. N. and Mc Cuistions W. L. (2005). Response of flower and boll development to climatic factors before and after anthesis in Egyptian cotton. Clim. Res., 29: 167-179.

Sawan Z. M., Li H. N., Mc Cuistions W. L. and Foote R. J. (2010). Egyptian cotton 
(Gossypium barbadense L.) flower and boll production as affected by climatic factors and soil moisture status. Theor. and Appl. Clim., 99: 217-227.

Shafshak S. E., Kasem M. M., Awad H. Y. and Awaad M. M. (1993). Breeding behaviour of some characters in lines derived from an Egyptian cotton hybrid. 1- Earliness characters. Ann. Agric. Sci., Moshtohor, 31: 693-700.

Shah M. K. N., Malik S. A., Murtaza N., Ullah I., Rahman H. and Younis U. (2010).
Early and rapid flowering coupled with shorter boll maturation period offers selection criteria for early crop maturity in upland cotton. Pak. J. Bot. 42(5):3569 3576.

Shakeel A., Farooq J., Bibi A., Khan Sh. H. and Saleem M. F. (2012). Genetic studies of earliness in Gossypium hirsutum L. IJAVMS, 6: 189-207.

Snedecor G. W. and Cochran W. G. (1967). Statistical methods. lowa State Univ., Press. Ames, lowa. U. S. A.

$$
\begin{aligned}
& \text { استخدام طرق مختلفة لقياس التبكير في بعض التراكيب } \\
& \text { الوراثية للقطن المصري } \\
& \text { أيمن حمدي علي مهذيـ حسين صلاح خليفة" ـ صلاح الدين رشاد نصر سعيد" } \\
& \text { قسم المحاصيل ـ كلية الزر اعة ـ جامعة الفيوم ـ مصر *معهد بحوث القطن ـ مركز البحوث الزر اعية ـ الجيزة ـ مصر } \\
& \text { ملخص }
\end{aligned}
$$

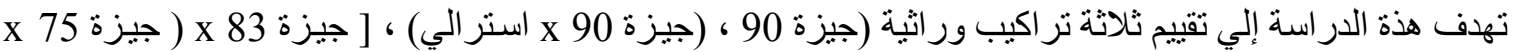

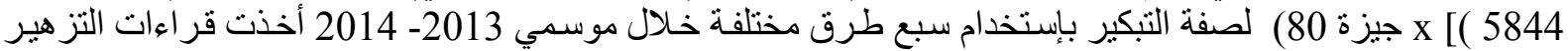

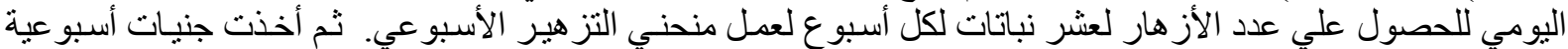

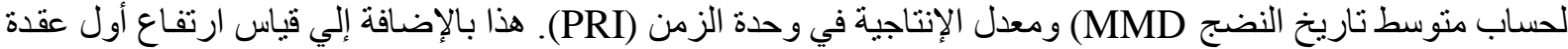

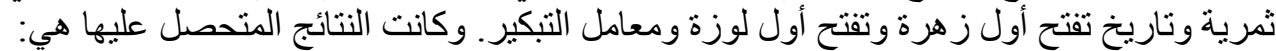

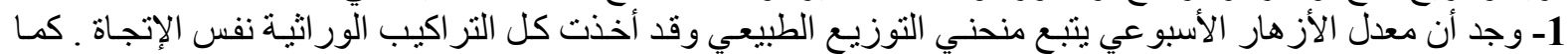

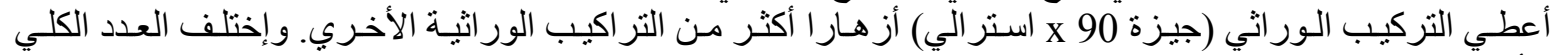

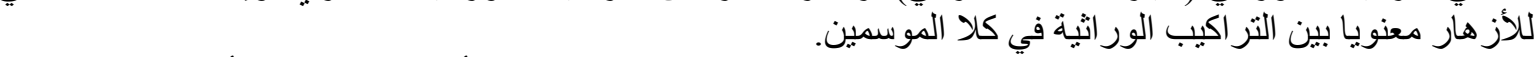

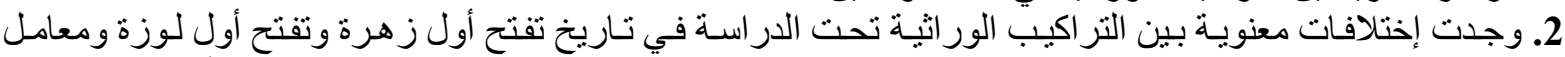

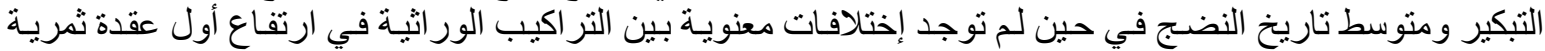

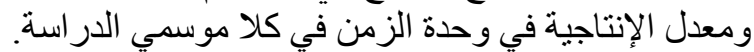

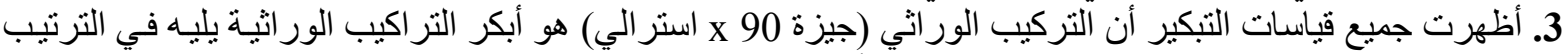

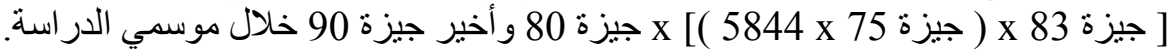
المجلة العلمية لكلية الزراعة - جامعة القاهرة - المجلد (65) العدد الرابع (أكتوبر 2014):454-448. 